\title{
ANALISIS FAKTOR-FAKTOR YANG MEMPENGARUHI LOYALITAS KARYAWAN PADA PERTOKOAN DI SEPANJANG JALAN MALIOBORO YOGYAKARTA
}

\author{
Yati Suhartini \\ Universitas PGRI Yogyakarta, Jl.PGRI I No.117 Sonosewu, Yogyakarta. \\ email:yati.suhartini@yahoo.com
}

\begin{abstract}
The research was carried out to know the influence of career development, compensation and job characteristics to employee loyalty at stores along Malioboro street, Yogyakarta.

The population of the research were all of Sales Promotion Girls (SPG) and Sales Promotion Boys (SPB) working at stores along Malioboro street. Samples were taken with non-probability sampling technique by quota sampling, as many as 100 respondents. The data was collected by applying questionnaires, and analyzed by using multiple linear regressions with the help of SPSS program for windows release 16.0.

This research concluded that factors of career development, compensation and job characteristics, partially or simultaneously showed a positive and significant influence to employee loyalty. These were indicated by the regression coefficient value of each factor of career development, compensation and job characteristics to employee loyalty were 0.421 (X1); 0.149 (X2); 0.411 (X3); and the significant level of each factor were 0.000; 0.45 and 0.000, respectively. While the value of $F$ amounting to 51.235 with the sign.ificance level of 0.000; whereas adjusted $R$ square equal to 0.604 .
\end{abstract}

Keywords: Career development, compensation and job characteristics toward employee loyalty.

\section{Pendahuluan}

Pertokoan sepanjang jalan Malioboro Yogyakarta merupakan salah satu pusat perbelanjaan besar di Yogyakarta. Produk produk yang ditawarkan didalamnya menganut produk trend dari dalam negeri maupun luar negeri, seperti pakaian, makanan dan bahkan barang barang elektronik. Hal ini menjadikan pasar yang ada akan semakin ketat dalam persaingan. Produk yang baik dan harga yang bersaing tentunya perlu ditunjang dengan sumber daya manusia yang baik juga.

Kemampuan menawarkan yang dimiliki Sales Promotion Girl (SPG) dan Sales Promotion Boy (SPB) menjadi ujung tombak perusahaan dalam memasarkan produknya. Menurut direct brand manager pertokoan, persaingan mencari SPG dan SPB yang handal terjadi antar perusahaan yang ada di dalam pertokoan sepanjang Malioboro Yogyakarta. Selain itu, masalah crusial yang sering dihadapi perusahaan adalah kurangnya loyalitas karyawan terhadap perusahaan. $\mathrm{Pa}$ dahal, loyalitas sangat berpengaruh terhadap kinerja perusahaan.

Pentingnya loyalitas karyawan pada hasil kinerja perusahaan, maka perusahaan perlu meningkatkan perhatiannya terhadap usaha-usaha mempertahankan dan menjaga loyalitas karyawan tersebut. Dalam mempertahankan loyalitas, masing masing perusahaan tentunya memiliki cara dan rahasia tersendiri. Namun tentunya semua cara mengacu kepada apa yang diberikan perusahaan kepada karyawan SPG dan SPB tersebut.

Banyak faktor-faktor yang mempengaruhi kurangnya loyalitas karyawan terhadap 
suatu perusahaan, salah satunya adalah faktor pengembangan karir. Tentu saja harapan seorang SPG dan SPB tidak serta merta terus menerus berada dalam satu tingkatan jabatan tersebut. Keinginan untuk maju dan meningkat pasti selalu ada. Apalagi tingkatan jabatan dalam suatu perusahaan sangat beragam dari SPG/ SPB, Supervisor, manajer bagian, hingga kepala manajer. Salah satu supervisor toko di Malioboro menjelaskan bahwa yang sering terjadi di lapangan adalah pengembangan karir terjadi pada karyawan yang bekerja cukup lama dalam satu perusahaan. Namun tidak menutup kemungkinan seorang yang belum lama bergabung dalam suatu perusahaan karirnya akan cepat naik. Realita yang terjadi tersebut sering berimbas pada loyalitas karyawan SPG dan SPB terhadap perusahaan. Hal tersebut sesuai dengan pendapat Mangkunegara (2001), bahwa pengembangan karir yang baik dari perusahaan akan memunculkan loyalitas karyawan terhadap perusahaan.

Faktor lain yang sering dijumpai yaitu karyawan mengukur loyalitas melalui kompensasi yang diberikan oleh perusahaan kepada karyawan sebagai imbalan atas pekerjaanya. Kompensasi yang diberikan perusahaan satu dengan yang lain berbeda beda dan bahkan setiap karyawan mendapatkan kompensasi yang berbeda. Perbedaan dalam pemberian kompensasi inilah yang sering mempengaruhi loyalitas karyawan terhadap perusahaan. Gouzali Saydam (2005) mengungkapkan bahwa kompensasi merupakan salah satu faktor yang mempengaruhi loyalitas karyawan. Oleh karena itu kompensasi harus diperhatikan oleh perusahaan.

Seorang SPG dan SPB selain harus memiliki tubuh yang ideal dan wajah yang mendukung, juga harus pintar menyesuaikan dengan karakter pekerjaanya karena produk yang berbeda dan perusahaan yang berbeda akan berbeda juga karakteristik pekerjaanya. Griffin (2013) mengemukakan bahwa karakteristik pekerjaan yang baik akan memunculkan loyalitas yang baik pula, ditandai dengan adanya motivasi yang tinggi, kualitas kerja tinggi, kepuasan terhadap pekerjaanya, ketidakhadiran dan tingkat perputaran yang rendah. Artinya karakteristik pekerjaan berpengaruh positif terhadap loyalitas karyawan.

Latar belakang tersebut di atas menjadi dasar dilakukannya penelitian ini dengan judul "Analisis Faktor-Faktor yang Mempengaruhi Loyalitas Karyawan pada Pertokoan di sepanjang jalan Malioboro Yogyakarta”

\section{Perumusan Masalah}

Adapun rumusan masalah dalam penelitian ini adalah sebagai berikut:

1. Apakah pengembangan karir berpengaruh terhadap loyalitas karyawan pada pertokoan di sepanjang jalan malioboro Yogyakarta?

2. Apakah kompensasi berpengaruh terhadap loyalitas karyawan pada pertokoan di sepanjang jalan malioboro Yogyakarta?

3. Apakah karakteristik pekerjaan berpengaruh terhadap loyalitas karyawan pada pertokoan di sepanjang jalan malioboro Yogyakarta?

4. Apakah pengembangan karir, kompensasi dan karakteristik pekerjaan secara simultan berpengaruh terhadap loyalitas karyawan pada pertokoan di sepanjang jalan malioboro Yogyakarta?

\section{Tujuan Penelitian}

Berdasarkan permasalahan diatas, maka tujuan penelitian secara umum adalah untuk menguji dan mengetahui pengaruh faktor pengembangan karir, kompensasi dan karakteristik pekerjaan terhadap loyalitas karyawan SPG dan SPB pada pertokoan di sepanjang jalan Malioboro Yogyakarta, baik secara parsial maupun simultan.

\section{Kajian Teori}

\section{Pengembangan Karier}

\section{Pengertian pengembangan karier}

Robins (2016;254) mengatakan pengembangan karir merupakan suatu cara 
bagi sebuah organisasi untuk mendukung atau meningkatkan produktivitas para karyawan dewasa ini, sementara sekaligus mempersiapkan mereka untuk dunia yang berubah.

Rivai dan Jauvani (2011;120) pengembangan karier adalah proses peningkatan kemampuan kerja individu yang dicapai dalam rangka mencapai karir yang diinginkan. Tujuan dari seluruh program pengembangan karir adalah untuk menyesuaikan antara kebutuhan dan tujuan karyawan dengan kesempatan karir yang tersedia diperusahaan saat ini dan di masa mendatang.

Pendapat lain mengatakan bahwa pengembangan karier merupakan upaya pribadi seseorang dalam mewujudkan rencana karirnya, perwujudan ini bisa didukung atau tidak didukung oleh departemen SDM (Wahyono, 2015:121).

\section{Faktor - Faktor Pengembangan Karier}

Faktor-faktor pengembangan karir menurut Wahyono (2015:121), antara lain:

1) Kinerja; prestasi kerja adalah hal utama yang harus ditunjukan oleh setiap karyawan bila ingin membangun kariernya dengan baik dan mulus, tanpa prestasi kerja yang baik mustahil suatu jernjang karier akan mudah dilalui.

2) Exposure; pandai mempromosikan diri pada saat yang tepat. Biasanya terdapat cara yang dapat digunakan untuk itu, yaitu saat presentasi hasil karya, laporan tertulis, laporan lisan kepada atasan, keaktifan dan keberhasilan di kepanitiaan, dan hubungan baik dengan lingkungan bisnis.

3) Leveraging; permintaan berhenti untuk melanjutkan pekerjaan diperusahaan lain sering kali digunakan karyawan untuk membangun karier yang lebih baik.

4) Dedikasi; kesetiaan jangka panjang biasanya lebih dihargai dalam perbaikan karier. Karyawan yang mempunyai pengalaman kerja disuatu perusahaan dalam jangka yang cukup lama pada umumnya mempunyai dedikasi yang lebih baik dibanding yang sering berpindah- pindah perusahaan dalam jangka waktu pendek.

5) Mentor dan sponsor; mentor adalah orang yang menawarkan bimbingan karier informal, sedangkan sponsor adalah orang dalam organisasi yang dapat menciptakan kesempatan-kesempatan pengembangan karier bagi orang lain.

6) Edukasi; pendidikan, latihan, dan kursus-kursus tambahan yang bertujuan menambah keahlian serta keterampilan karyawan dengan sertifikat yang mendukung akan membantu karier seseorang.

\section{Kompensasi}

\section{Pengertian Kompensasi}

Kompensasi adalah segala sesuatu yang diterima karyawan sebagai imbalan atas sumbanganya kepada perusahaan, termasuk di dalamnyaa gaji, pemberian tunjangan, fasilitas-fasilitas yang dapat dinikmati karyawan, baik berupa uang maupun bukana (Wahyono 2015:150).

Gary Dessler (2016:418) mengatakan bahwa kompensasi adalah segala bentuk pembayaran atau imbalan yang diberikan kepada karyawan dan timbul dari hubungan kerja mereka.

Rivai dan Jauvani (2011:741) Kompensasi merupakan sesuatu yang diterima karyawan sebagai pengganti kontribusi jasa mereka pada perusahaan.

\section{Tujuan Kompensasi}

Kompensasi yang diberikan perusahaan berbeda-beda antara karyawan satu dengan yang lainya. Kompensasi juga sangat sensitif bagi manajemen perusahaan dalam pelaksanaanya. Dengan adanya tujuan kompensasi yang jelas maka perusahaan perlu serius dalam memberikan kompensasi kepada karyawan.

Tujuan dari diberikanya kompensasi antara lain (Hasibuan 2013:121 ):

a. Ikatan kerja sama, dengan pemberian kompensasi terjalinlah ikatan kerjasama formal antara majikan dengan karyawan. 
Karyawan wajib mengerjakan tugas-tugasnya dengan baik, sedangkan pengusaha atau majikan wajib membayar kompensasi sesuai dengan perjanjian yang disepakati.

b. Kepuasan kerja, dengan balas jasa karyawan akan memenuhi kebutuhan-kebutuhan fisik, status sosial, dan egoistiknya sehingga memperoleh kepuasan kerja dari jabatanya.

c. Pengadaan efektif, jika program kompensasi ditetapkan cukup besar, pengadaan karyawan yang qualified untuk perusahaan akan lebih mudah.

d. Motivasi, jika balas jasa yang diberikan cukup besar, manajer akan lebih mudah memotivasi bawahanya.

e. Stabilitas karyawan, dengan program kompensasi atas prinsip adil dan layak serta eksternal konsistensi yang kompetitif maka stabilitas karyawan akan lebih terjamin karena turn over relatif kecil.

f. Disiplin, dengan pemberian balas jasa yang cukup besar maka disiplin karyawan semakin baik, mereka akan menyadari serta menaati peraturan-peraturan yang berlaku.

g. Pengaruh serikat buruh, dengan program kompensasi yang baik, pengaruh serikat buruh dapat dihindari dan karyawan akan berkonsentrasi pada pekerjaanya.

h. Pengaruh pemerintah, jika program kompensasi sesuai dengan undang-undang perburuhan yang berlaku (seperti batas upah minimum) maka investasi pemerintah dapat dihindari.

\section{Komponen-Komponen Kompensasi}

Komponen komponen kompensasi antara lain (Rivai dan Jauvani 2011:744):

1) Gaji.

Gaji adalah balas jasa dalam bentuk uang yang diterima karyawan sebagai konsekuensi dari kedudukanya sebagai seorang karyawan yang memberikan sumbangan tenaga dan pikiran dalam mencapai tujuan perusahaan FG.

2) Upah.

Upah merupakan imbalan finansial langsung yang dibayarkan kepada karyawan berdasarkan jam kerja, jumlah barang yang dihasilkan atau banyaknya pelayanan yang diberikan.

3) Insentif.

Insentif merupakan imbalan langsung yang dibayarkan kepada karyawan karena kinerjanya melebihi standar yang ditentukan.

4) Kompensasi tidak langsung (Fringe benefit).

Fringe Benefit Merupakan kompensasi tambahan yang diberikan berdasarkan kebijakan perusahaan terhadap semua karyawan sebagai upaya meningkatkan kesejahteraan para karyawan.

\section{Faktor-Faktor yang Mempengaruhi Kompensasi}

Menentukan penggajian atau kompensasi disuatu perusahaan tidaklah mudah karena menyangkut bagaimana mempertahankan tenaga kerja trampil yang dimiliki perusahaan, supaya tidak direkrut oleh pesaing serta kesesuaian dan keadilan setiap posisi dalam perusahaan. Untuk itu terdapat faktor-faktor yang mempengaruhi besarnya kompensasi antara lain (Riani 2013;120):

1) Jenis keahlian yang dibutuhkan.

2) Jenis bisnis.

3) Keikutsertaan dalam serikat pekerja.

4) Intensif modal vs intensif tenaga kerja.

5) Ukuran bisnis.

6) Filosofi Manajemen.

7) Total paket kompensasi.

8) Lokasi geografis.

9) Penawaran dan permintaan tenaga kerja.

10) Laba perusahaan.

11) Stabilitas pegawai.

12) Perbedaan gender.

13) Kinerja dan masa kerja pegawai.

\section{Karakteristik Pekerjaan}

\section{Pengertian Karakteristik Pekerjaan}

Wayne Mondy (2008;61) mengatakan bahwa karakteristik pekerjaan meliputi lima dimensi pekerjaan inti yaitu variasi 
keterampilan, identitas tugas, signifikasi tugas, otonomi dan umpan balik.

Griffin (2013;129) menemukakan bahwa karakteristik pekerjaan adalah tentang bagaimana mendesain pekerjaan dengan menggunakan lima karakteristik inti yang berupa variasi keterampilan, identitas tugas, arti tugas, otonomi, dan umpan balik yang mempengaruhi variasi personal dan hasil kerja.

Pendapat lain oleh Luthan (2013;563), karakteristik pekerjaan merupakan bagian dari desain tugas yang berupa ruang ligkup kerja yang memiliki dimensi macam-macam kemampuan, identitas tugas, sign.ifikansi tugas, otonomi, dan umpan balik.

\section{Teori Karakteristik Pekerjaan}

Teori karakteristik pekerjaan merupakan suatu model kontemporer yang penting tentang bagaimana mendesain pekerjaan, dengan menggunakan lima karakteristik pekerjaan inti, para manajer dapat meningkatkan tiga keadaan psikologis kritis, keadaan ini nantinya dapat meningkatkan variasi personal dan hasil kerja. Perbedaan individual juga mempengaruhi bagaimana karakteristik pekerjaan mempengaruhi orang-orang (Griffin 2013;129).

Jika suatu kasus seorang karyawan mengalami keadaan-keadaan motivasi kerja yang tinggi, kinerja kerja kualitas tinggi, kepuasan yang tinggi dengan pekerjaanya, dan ketidakhadiran serta perputaran yang rendah, maka kemungkinan besar karyawan merasa baik tentang dirinya sendiri dan merespon secara baik terhadap pekerjaan mereka (Griffin 2013;129).

\section{Keadaan Psikologis Kritis Karyawan}

Dalam meningkatkan respon karyawan terhadap karakteristik pekerjaan terdapat tiga keadaan psikologis kritis karyawan, antara lain (Griffin 2013;128):

1) Keberartian yang dialami dari pekerjaan tersebut, yaitu bagaimana individu mengalami pekerjaan tersebut sebagai suatu yang pada umumnya berarti, bernilai dan berharga
2) Tanggung jawab yang dialami untuk hasil kerja, yaitu sejauh mana individu-individu merasa secara personal bertanggung jawab atas hasil dari kerja mereka.

3) Pengetahuan terhadap hasil, yaitu sejauh mana individu-individu secara kontinu mengerti seberapa efektif mereka melakukan pekerjaan tersebut.

\section{Loyalitas karyawan}

\section{Pengertian Loyalitas}

Loyalitas atau kesetiaan merupakan salah satu unsur yang digunakan dalam penilaian karyawan yang mencakup kesetiaan terhadap pekerjaannya, jabatannya dan organisasi. Kesetiaan ini dicerminkan oleh kesediaan karyawan menjaga dan membela organisasi didalam maupun diluar pekerjaan dari rongrongan orang yang tidak bertanggungjawab (Hasibuan 2013:58).

Menurut Saydam Gouzali (2005:417) loyalitas adalah sikap positif karyawan terhadap kondisi yang terjadi dalam perusahaan baik mengarah pada kemajuan perusahaan maupun yang mengarah pada kecenderungan yang merugikan.

Runtu (2013:2) mengemukakan bahwa loyalitas secara tradisional, dipahami sebagai sesuatu yang dengan sendirinya tercipta. Ketika seseorang bergabung dengan perusahaan, dengan sendirinya dia akan bersikap loyal, bertahan dalam organisasi dan melakukan yang terbaik untuk organisasi.

\section{Manfaat Loyalitas Karyawan}

Loyalitas yang baik akan menghasilkan sumber daya yang memiliki kriteria antara lain (Saydam Gouzali 2005:416):

1) Mempunyai kepedulian yang tinggi terhadap perusahaan.

2) Merasa memiliki terhadap perusahaan.

3) Dapat mencegah terjadinya turn over karyawan.

4) Menjamin kesinambungan kinerja perusahaan.

5) Menjamin tetap terpeliharanya motivasi kerja. 
6) Meningkatkan profesionalisme dan produktivitas kerja.

\section{Kerangka Konseptual Penelitian}

Berdasarkan kajian teori diatas, kerangka konseptual yang mendasari penelitian ini digambarkan sebagai berikut:

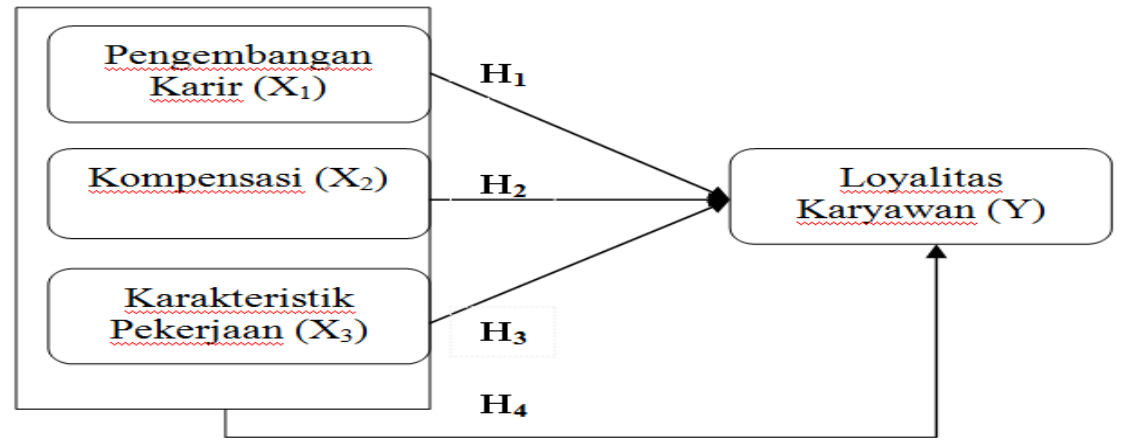

Gambar 1. Kerangka Konseptual Penelitian.

\section{Perumusan Hipotesis}

Dari perumusan masalah, landasan teori dan kerangka konseptual, maka dapat ditarik hipotesis, sebagai berikut:

H1: Diduga pengembangan karir berpengaruh positif terhadap loyalitas karyawan pada pertokoan di sepanjang jalan Malioboro Yogyakarta.

H2: Diduga kompensasi berpengaruh positif terhadap loyalitas karyawan pada pertokoan di sepanjang jalan Malioboro Yogyakarta.

H3: Diduga karakteristik pekerjaan berpengaruh positif terhadap loyalitas karyawan pada pertokoan di sepanjang jalan Malioboro Yogyakarta.

H4: Diduga pengembangan karir, kompensasi dan karakteristik pekerjaan secara simultan berpengaruh positif terhadap loyalitas karyawan pada pertokoan di sepanjang jalan Malioboro Yogyakarta.

\section{Metode Penelitian}

\section{Populasi dan Sampel Penelitian}

Populasi penelitian ini yaitu seluruh karyawan Sales Promotion Girl (SPG) dan Sales Promotion Boy (SPB) yang bekerja di pertokoan sepanjang jalan Malioboro, Yogyakarta. Penelitian ini menggunakan sampel dan pengambilan sampel menggunakan teknik Non-Probability Sampling dengan cara sampel kuota sebanyak 100 responden.

\section{Variabel dan Indikator Penelitian}

Variabel penelitian ini meliputi variabel independen dan variabel dependen.

a. Variabel independen (X) terdiri dari pengembangan karir $\left(\mathrm{X}_{1}\right)$, kompensasi $\left(\mathrm{X}_{2}\right)$, dan karakteristik pekerjaan $\left(\mathrm{X}_{3}\right)$.

1) Pengembangan karir $\left(X_{1}\right)$, dalam penelitian ini diukur dengan indikator (Wahyono 2015):

- Kinerja: Adanya pengembangan karir melalui evaluasi prestasi kerja.

- Exposure: Adanya pengembangan karir melalui promosi dari hasil karya.

- Leveraging: Adanya promosi jabatan dengan riwayat kerja dari perusahaan sebelumnya.

- Dedikasi: Kesetiaan dihargai dengan pengembangan karir yang baik.

- Mentor dan sponsor: Perusahaan memberikan kesempatan berkarir yang adil; perusahaan memiliki pemimpin dan sponsor yang membimbing karir karyawan.

- Edukasi: Perusahaan memberikan pelatihan sebagai pengembangan karir karyawan. 
2) Komnpensasi $\left(X_{2}\right)$, dalam penelitian ini diukur dengan indikator (Gary Dessler, 2016:417):

- Upah; perusahaan memberikan pembayaran sesuai jam kerja.

- Gaji; perusahaan memberikan bayaran sesuai kontrak kerja.

- Insentif; perusahaan memberikan bayaran ketika bekerja melebihi target.

- Komisi; adanya bayaran tambahan atas penjualan produk.

- Bonus; adanya bonus yang diberikan oleh perusahaan.

- Asuransi; adanya asuransi kesehatan dari perusahaan.

- Liburan; perusahaan sering mengadakan liburan bersama/family gathering.

3) Karakteristik pekerjaan $\left(X_{3}\right)$, dalam penelitian ini diukur dengan indikator Wayne Mondy (2008:61-62):

- Variasi keterampilan; pekerjaan membutuhkan keterampilan khusus.

- Identitas tugas; pekerjaan dapat di identifikasi dengan mudah.

- Sign.ifikasi tugas; tugas yang dilakukan bermanfaat kepada orang lain.

- Otonomi; pekerjaan bebas dijalankan sesuai tanggung jawab.

- Umpan balik; adanya informasi tentang hasil kinerja karyawan.

b. Variabel dependen (Y), yaitu Loyalitas karyawan yang diukur dengan indikator Saydam Gozali (2005):

- Ketaatan dan kepatuhan: karyawan selalu taat dengan peraturan perusahaan; karyawan patuh dengan atasan sesuai wewenang di perusahaan.

- Tanggung jawab: Selalu menyelesaikan pekerjaan sesuai waktu; selalu menggunakan fasilitas perusahaan dengan baik.

- Pengabdian: Menyumbangkan tenaga dan pikiran dengan ikhlas kepada perusahaan.
- Kejujuran: Menyimpan rahasia perusahaan dari perusahaan lain; selalu melaporkan semua kegiatan kepada atasan.

\section{Instrumen Penelitian, Cara Pengukuran, dan Teknik Pengumpulan Data}

Penyusunan instrumen penelitian yang berupa butir-butir soal (kuesioner) didasarkan atas kisi-kisi kuesioner yang telah dikontruksi sesuai landasan teori yang telah dikaji dan berpedoman pada indikator dari variabel-variabel penelitian yang dijabarkan dalam beberapa butir soal. Semua butir soal dalam kuesioner berupa pertanyaan objektif sehingga responden hanya memberi tanda silang (X) pada salah satu jawaban yang dianggap paling sesuai dengan keadaannya. Setelah kuesioner disusun, butir-butir kuesioner tersebut diuji cobakan kepada 30 responden untuk mengetahui validitas dan reliabilitas instrumen. Selanjutnya, kuesioner yang lolos pada pegujian awal tersebut kemudian disebarkan kepada 100 responden yang berbeda dari responden pada langkah uji coba.

Untuk mengukur jawaban responden dipergunakan skala bertingkat model Likert dengan 5 altematif jawaban. Agar data yang diperoleh berwujud data kuantitatif, maka setiap butir soal diberi skor sesuai jawabannya, yaitu jawaban: Sangat Tidak Setuju $=1$, Tidak Setuju $=2$, Kurang Setuju $=3$, Setuju $=4$, Sangat Setuju $=$ 5. (Sugiyono, 2014).

\section{Teknik Analisis Data}

\section{Analisis Regresi Linier Berganda}

Analisis regresi linier berganda adalah hubungan secara linear antara dua atau lebih variabel bebas $\left(\mathrm{X}_{1}, \mathrm{X}_{2}, \ldots . \mathrm{X}_{\mathrm{n}}\right)$ dengan variabel terikat (Y). Analisis ini untuk mengetahui apakah masing-masing variabel bebas berhubungan positif atau negatif dan untuk memprediksi nilai dari variabel terikat apabila nilai variabel independen mengalami 
kenaikan atau penurunan. (Dwi Consultan :2011, online).

Persamaan regresi linear berganda sebagai berikut:

$$
\mathbf{Y}=\mathbf{a}+\mathbf{b}_{1} \mathbf{X}_{1}+\mathbf{b}_{2} \mathbf{X}_{2}+\mathbf{b}_{3} \mathbf{X}_{3}
$$

Keterangan:

\begin{tabular}{|c|c|}
\hline $\mathbf{Y}$ & $\begin{array}{l}\text { : variabel terikat (dependent) } \\
=\text { loyalitas karyawan. }\end{array}$ \\
\hline $\begin{array}{l}X \\
(1,2,3, \ldots)\end{array}$ & $\begin{array}{l}\text { variabel bebas (independent) } \\
=\text { pengembangan karir, kom- } \\
\text { pensasi, karakteristik peker- } \\
\text { jaan. }\end{array}$ \\
\hline & $\begin{array}{l}\text { : konstanta dari rata-rata nilai } \\
\text { Y pada saat } \mathrm{X}(1,2,3 . .) \text { sama } \\
\text { dengan nol. }\end{array}$ \\
\hline $2,3, \ldots)$ & nilai koefisien regresi. \\
\hline
\end{tabular}

Uji Hipotesis

\section{Uji t}

Uji t digunakan untuk mengetahui pengaruh dari masing-masing variabel bebas terhadap variabel terikat. Dasar pengambilan keputusan Uji t parsial dengan output SPSS sebagai berikut: (SPSS Indonesia, online). SPSS:

Berdasarkan nilai sign.ifikan hasil output

- Jika nilai Sig. < o,05 maka veriabel bebas berpengaruh signifikan terhadap variabel terikat.

- Jika nilai Sig. > 0,05 maka variabel bebas tidak berpengaruh signifikan terhadap variabel terikat.

- Tingkat kepercayaan yang digunakan adalah 95\%, maka nilai $\alpha=0,05$.

\section{Uji F}

Uji F bertujuan untuk mengetahui apakah variabel bebas secara bersama-sama atau simultan berpengaruh terhadap variabel terikat. Dasar pengambilan keputusan Uji F dengan output SPSS sebagai berikut: (SPSS Indonesia, online).

- Jika nilai Sig. <0,05 maka veriabel be- bas secara simultan berpengaruh signifikan terhadap variabel terikat.

- Jika nilai Sig. > 0,05 maka variabel bebas secara simultan tidak berpengaruh signifikan terhadap variabel terikat.

- Tingkat kepercayaan yang digunakan adalah 95\%, maka nilai $\alpha=0,05$.

\section{Koefisiensi Determinasi ( $\mathbf{R}^{2}$ )}

Besarnya koefisien determinasi $\left(\mathrm{R}^{2}\right)$ menunjukkan persentase pengaruh variabel bebas terhadap variabel terikat. Apabila $\mathrm{R}^{2}=$ 0 , maka model regresi yang digunakan tidak menjelaskan sedikitpun variasi dari nilai $Y$. Apabila $\mathrm{R}^{2}=1$, maka model yang digunakan menjelaskan $100 \%$ variasi dari nilai Y atau terjadi kecocokan sempurna. (Darmawan, 2013).

Nilai koefisien determinasi yang digunakan dalam penelitian ini adalah nilai Adjusted $\mathrm{R}^{2}$ karena variabel independen yang digunakan dalam penelitian ini lebih dari dua variabel. Selain itu nilai Adjusted $\mathrm{R}^{2}$ dianggap lebih baik dari nilai $\mathrm{R}^{2}$, karena $\mathrm{R}^{2}$ tidak memiliki faktor koreksi sehingga jika dalam model, variabel bebas terus ditambah, maka nilainya akan terus membesar. Sementara itu, penambahan variabel bebas belum tentu menaikkan angka adjusted $\mathrm{R}^{2}$ sebab ia mampu menjelaskan apakah proporsi keragaman variabel terikat (dependen) mampu dijelaskan oleh variabel bebas atau tidak. Penambahan variabel bebas tentu belum menjadi jaminan nilai adjusted $R$ square meningkat sebab bisa saja terdapat variabel yang sebenarnya tidak mampu menjelaskan proporsi keragaman variabel terikat malah masuk dalam model sehingga secara implisit merusak model. (Kompasiana: 2014, online)

\section{Hasil Penelitian}

\section{Karakteristik Responden}

Penelitian ini menggunakan sampel sebanyak 100 responden yaitu karyawan SPG dan SPB yang bekerja pada pertokoan di sepanjang jalan Malioboro Yogyakarta, yang 
karakteristiknya disajikan melalui tabel dibawah ini.

a. Karakteristik Responden Berdasarkan Jenis kelamin.

Tabel 1. Jenis Kelamin Responden.

\begin{tabular}{lcc}
\hline $\begin{array}{c}\text { Jenis } \\
\text { Kelamin }\end{array}$ & Frekuensi & $\begin{array}{c}\text { Persentase } \\
\text { (\%) }\end{array}$ \\
\hline Laki-laki & 45 & 45 \\
Perempuan & 55 & 55 \\
\hline Total & $\mathbf{1 0 0}$ & $\mathbf{1 0 0}$ \\
\hline
\end{tabular}

Sumber : Data primer diolah, 2017.

b. Karakteristik Responden Berdasarkan Umur.

Tabel 2. Usia Responden.

\begin{tabular}{ccc}
\hline Usia/Tahun & Frekuensi & Persentase (\%) \\
\hline$<20$ & 17 & 17 \\
$20-30$ & 75 & 75 \\
$>30$ & 8 & 8 \\
\hline Total & $\mathbf{1 0 0}$ & $\mathbf{1 0 0}$ \\
\hline
\end{tabular}

Sumber : Data primer diolah, 2017.

c. Karakteristik Responden Berdasarkan Lama Kerja.

Tabel 3. Lama Kerja Responden.

\begin{tabular}{lcc}
\hline Lama Kerja & Frekuensi & Persentase (\%) \\
\hline$<5$ tahun & 63 & 63 \\
$>10$ tahun & 7 & 7 \\
$5-10$ tahun & 30 & 30 \\
\hline Total & $\mathbf{1 0 0}$ & $\mathbf{1 0 0}$
\end{tabular}

Sumber : Data primer diolah, 2017.

d. Karakteristik Responden Berdasarkan Pendidikan.

Tabel 4. Pendidikan Responden.

\begin{tabular}{lcc}
\hline Pendidikan & Frekuensi & Persentase (\%) \\
\hline Diploma & 11 & 11 \\
Sarjana & 6 & 6 \\
SMA & 83 & 83 \\
\hline Total & $\mathbf{1 0 0}$ & $\mathbf{1 0 0}$
\end{tabular}

Sumber : Data primer diolah, 2017.

\section{Hasil Uji Validitas dan Reliabilitas}

\section{Hasil uji validitas}

Hasil uji validitas menyatakan bahwa semua butir pernyataan/pertanyaan dapat dikatakan valid. Hal ini dapat dilihat dari nilai sig yang berada dibawah taraf signifikansi yaitu 5\% atau 0.05. Berikut tabel hasil uji validitas instrumen menggunakan bantuan SPSS for windows release 16.0:

\section{Tabel 5. Hasil Uji Validitas.}

\begin{tabular}{|c|c|c|c|}
\hline Variabel & Item & Sig. & Keterangan \\
\hline \multirow{7}{*}{$\begin{array}{l}\text { Pengembangan } \\
\text { karir }\end{array}$} & $\mathrm{X} 1.1$ & 0,000 & Valid \\
\hline & $\mathrm{X} 1.2$ & 0,000 & Valid \\
\hline & X1.3 & 0,000 & Valid \\
\hline & X1.4 & 0,000 & Valid \\
\hline & X1.5 & 0,000 & Valid \\
\hline & X1.6 & 0,000 & Valid \\
\hline & $\mathrm{X} 1.7$ & 0,000 & Valid \\
\hline \multirow{7}{*}{ Kompensasi } & X2.1 & 0,000 & Valid \\
\hline & $\mathrm{X} 2.2$ & 0,022 & Valid \\
\hline & X2.3 & 0,000 & Valid \\
\hline & $\mathrm{X} 2.4$ & 0,000 & Valid \\
\hline & X2.5 & 0,000 & Valid \\
\hline & X2.6 & 0,000 & Valid \\
\hline & $\mathrm{X} 2.7$ & 0,000 & Valid \\
\hline \multirow{4}{*}{$\begin{array}{l}\text { Karakteristik } \\
\text { pekerjaan }\end{array}$} & X3.1 & 0,019 & Valid \\
\hline & X3.2 & 0,000 & Valid \\
\hline & X3.3 & 0,002 & Valid \\
\hline & X3.4 & 0,000 & Valid \\
\hline \multirow{8}{*}{$\begin{array}{l}\text { Loyalitas } \\
\text { karyawan }\end{array}$} & X3.5 & 0,000 & Valid \\
\hline & $\mathrm{Y} 1$ & 0,000 & Valid \\
\hline & Y2 & 0,004 & Valid \\
\hline & Y3 & 0,000 & Valid \\
\hline & Y4 & 0,000 & Valid \\
\hline & Y5 & 0,002 & Valid \\
\hline & Y6 & 0,000 & Valid \\
\hline & Y7 & 0,000 & Valid \\
\hline
\end{tabular}

Sumber: Data primer yang diolah, 2017. 


\section{Hasil Uji Reliabilitas.}

Hasil uji reliabilitas menyatakan bahwa semua butir pernyataan/pertanyaan dapat dikatakan reliabel. Hal ini dapat dilihat dari ni- lai Cronbach Alpha yang lebih besar dari 0,6 . Berikut tabel hasil uji reliabilitas instrumen menggunakan bantuan SPSS for windows release 16.0:

Tabel 6. Hasil Uji Reliabilitas.

\begin{tabular}{lcc}
\hline \multicolumn{1}{c}{ Variabel } & Nilai Cronbach alpha & Keterangan \\
\hline Pengembangan karir $\left(\mathrm{X}_{1}\right)$ & 0,860 & Reliabel \\
Kompensasi $\left(\mathrm{X}_{2}\right)$ & 0,821 & Reliabel \\
Karakteristik pekerjaan $\left(\mathrm{X}_{3}\right)$ & 0,701 & Reliabel \\
Loyalitas Karyawan $(\mathrm{Y})$ & 0,768 & Reliabel \\
\hline
\end{tabular}

Sumber: Data primer yang diolah, 2017.

Analisis Regresi Berganda

Persamaan Regresi dan Hasil Uji Parsial (Uji t).
Berikut ini tabel hasil analisis Regresi Linier Berganda dari output SPSS.

Tabel 7 . Hasil Regresi Linear Berganda dan Hasil Uji Parsial (Uji t).

\begin{tabular}{lccccc}
\hline \multicolumn{1}{c}{ Model } & $\begin{array}{c}\text { Koefisien } \\
\text { regresi }\end{array}$ & St.Error & t hitung & Sig. & Kesimpsulan \\
\hline (Constanta) & 4.786 & 1.950 & 2.455 & .016 & Sign.ifikan \\
Pengembangan karir & .421 & .070 & 5.976 & .000 & Sign.ifikan \\
Kompensasi & .149 & .073 & 2.030 & .045 & Sign.ifikan \\
Karakteristik pekerjaan & .411 & .114 & 3.619 & .000 & Sign.ifikan \\
\hline
\end{tabular}

Sumber : Data primer diolah, 2017.

Dari tabel 7 diperoleh persamaan regresi sebagai berikut:

$$
Y=4,786+0,421 X_{1}+0,149 X_{2}+0,411 X_{3}
$$

Dari tabel 7 diatas menunjukkan adanya pengaruh positif dan sign.ifikan dari variabel-variabel bebas $\mathrm{X}$ (pengembangan karir, kompensasi, dan karakteristik pekerjaan) terhadap variabel terikat Y (loyalitas karyawan), secara parsial.

\section{Hasil Uji Simultan (Uji F)}

Berikut ini tabel hasil uji simultan (uji F) dari output SPSS.

Tabel 8 . Hasil Uji Simultan (Uji F).

\begin{tabular}{lccccc}
\hline \multicolumn{1}{c}{ Model } & Sum of Square & df & Mean Square & F & Sig. \\
\hline Regression & 619.855 & 3 & 206.618 & 51.235 & $.000^{\mathrm{a}}$ \\
Residual & 387.145 & 96 & 4.033 & & \\
\hline Total & $\mathbf{1 0 0 7 . 0 0 0}$ & $\mathbf{9 9}$ & & & \\
\hline
\end{tabular}

Predictors: (Constant), PENG KARIR, KOMPENSASI, KARAKTER PEKERJAAN.

Dependent Variable: LOYALITAS.

Sumber : Data primer diolah, 2017. 
Dari tabel 8 diatas menunjukkan nilai Sig. yang diperoleh dari hasil uji $\mathrm{F}$ adalah sebesar 0,000 yang lebih kecil dari 0,05, artinya variabel pengembangan karir, kompensasi dan karakteristik pekerjaan secara simultan mempunyai pengaruh yang signifi- kan terhadap variabel loyalitas karyawan.

\section{Analisis Koefisiensi Determinasi ( $\left.\mathbf{R}^{2}\right)$}

Berikut ini tabel Uji Koefisien Determinasi dari output SPSS:

Tabel 9. Hasil Uji Koefisien Determinasi $\left(\mathbf{R}^{2}\right)$.

\begin{tabular}{ccccc}
\hline Model & $\mathbf{R}$ & $\boldsymbol{R}$ Square & Adjusted $\boldsymbol{R}$ Square & Std. Error of The Estimate \\
\hline 1 & $0.785^{\mathrm{a}}$ & 0.616 & 0,604 & 2.00817
\end{tabular}

a. Predictors: (Constant), Peng Karir, Kompensasi, Karakter Pekerjaan.

Sumber : Data Primer diolah, 2017.

Dari hasil uji $\mathrm{R}^{2}$ dengan menggunakan SPSS for windows 16.0 menyatakan bahwa nilai adjusted $\mathrm{R}^{2}=0,604$ artinya bahwa kemampuan variabel bebas $\left(\mathrm{X}_{1}, \mathrm{X}_{2}\right.$, $\mathrm{X}_{3}$ ) dalam menjelaskan besarnya pengaruh terhadap variabel terikat (Y) adalah sebesar $60,4 \%$, sedangkan sisanya $(39,6 \%)$ dijelaskan oleh variabel lain diluar penelitian ini.

\section{Pembahasan}

\section{Pengaruh Variabel Pengembagan Karir terhadap Variabel Loyalitas Karyawan.}

Hasil analisi data menunjukan bahwa koefisien regresi $b_{1}$ sebesar 0,421 dan hasil t-hitung sebesar 5.976 dengan tingkat signifikansi $0,000<0,05$, artinya variabel pengembangan karir $\left(\mathrm{X}_{1}\right)$ memiliki pengaruh positif dan signifikan terhadap loyalitas karyawan (Y), sehingga penelitian ini menerima hipotesis 1 yang menyatakan bahwa variabel pengembangan karir mempunyai pengaruh yang positif dan signifikan terhadap variabel loyalitas karyawan. Penelitian ini juga memberikan bukti empiris bahwa semakin baik pengembangan karir yang dilakukan perusahaan maka akan semakin meningkatkan loyalitas karyawan.

Hasil penelitian ini juga sesuai dengan teori yang dinyatakan oleh Anwar Prabu Mangkunegara (2001:77) bahwa tujuan pengembangan karir adalah meningkatkan hubungan kesejahteraan pegawai dengan meningkatnya kesejahteraan maka loyalitas akan bertambah tinggi. Jadi antara pengembangan karir dengan loyalitas karyawan terdapat pengaruh yang positif dimana pengembangan karir yang baik oleh organisasi akan memunculkan kesejahteraan karyawan yang akhirnya akan mendapatkan loyalitas yang tinggi.

Selain itu, hasil penelitian ini sejalan dengan penelitian yang dilakukan oleh Puji Lestari (2015) yaitu bahwa bahwa semakin tinggi pengembangan terhadap karir karyawan maka semakin tinggi pula loyalitas kerja pada karyawan, semakin rendah pengembangan karir yang diiberikan maka semakin menurun pula loyalitas karyawan. Hasil penelitian menunjukan bahwa pengembangan karir berpengaruh positif dan signifikan terhadap loyalitas karyawan.

\section{Pengaruh Variabel Kompensasi terhadap Variabel Loyalitas Karyawan.}

Hasil analisi data menunjukan bahwa koefisien regresi $b_{2}$ sebesar 0,149 dan hasil t-hitung sebesar 2.030 dengan tingkat signifikansi $0,045<0,05$, artinya variabel kompensasi $\left(\mathrm{X}_{2}\right)$ memiliki pengaruh positif dan sign.ifikan terhadap loyalitas karyawan (Y), sehingga penelitian ini menerima hipotesis 2 yang menyatakan bahwa variabel kompensasi mempunyai pengaruh yang positif dan sign.ifikan terhadap variabel loyalitas karyawan. Penelitian ini juga memberikan bukti 
empiris bahwa apabila kompensasi yang diberikan kepada karyawan ditingkatkan maka loyalitas karyawan juga akan meningkat.

Hasil penelitian ini juga sesuai dengan teori yang dikemukakan oleh Saydam Gouzali (2005:395) bahwa penyempurnaan sistem kompensasi yang baik dan tercipta keadilan secara eksternal akan memperbaiki dan meningkatkan loyalitas karyawan. Sehingga antara kompensasi dan loyalitas karyawan terdapat hubungan yang positif, artinya apabila kompensasi ditingkatkan maka loyalitas karyawan juga akan meningkat.

Selain itu, hasil penelitian ini sejalan dengan penelitian yang dilakukan oleh Rahmadana Safitri (2015) yang hasilnya menyimpulkan bahwa untuk meningkatkan loyalitas karyawan maka perusahaan harus menambah kompensasi yang diberikan kepada karyawan, atau bahkan menambah kompensasi baru untuk meningkatkan loyalitas karyawan. Hasil penelitiannya menunjukan bahwa kompensasi berpengaruh positif dan signifikan terhadap loyalitas karyawan.

\section{Pengaruh Variabel Karakteristik Pekerjaan terhadap Variabel Loyalitas Karyawan.}

Hasil analisi data menunjukan bahwa koefisien regresi $b_{3}$ sebesar 0,411 dan hasil t-hitung sebesar 3.619 dengan tingkat signifikansi $0,000<0,05$, artinya variabel karakteristik pekerjaan $\left(\mathrm{X}_{3}\right)$ memiliki pengaruh positif dan signifikan terhadap loyalitas karyawan (Y), sehingga penelitian ini menerima hipotesis 3 yang menyatakan bahwa variabel karakteristik pekerjaan mempunyai pengaruh yang positif dan signifikan terhadap variabel loyalitas karyawan. Penelitian ini juga memberikan bukti empiris bahwa semakin baik karakteristik pekerjaan maka akan semakin meningkatkan loyalitas karyawan.

Hasil penelitian ini juga sesuai dengan teori yang dinyatakan oleh Griffin (2013: 129) yaitu, bahwa karakterisitik pekerjaan yang baik akan memunculkan loyalitas yang baik pula, ditandai dengan adanya motivasi yang tinggi, kualitas kerja tinggi, kepuasan terhadap pekerjaanya, ketidakhadiran dan tingkat perputaran yang rendah. Artinya karakteristik pekerjaan berpengaruh positif terhadap loyalitas karyawan.

Selain itu, hasil penelitian ini sejalan dengan penelitian yang dilakukan oleh Silvia dkk. (2014) yaitu, bahwa apabila karakteristik pekerjaan yang diberikan kepada karyawan itu baik, maka akan memunculkan loyalitas yang baik pula pada karyawan. Hasil penelitian menunjukan bahwa karakteristik pekerjaan berpengaruh positif dan signifikan terhadap loyalitas karyawan.

\section{Pengaruh Variabel Pengembangan Karir, Kompensasi dan Karakteristik Pekerjaan Secara Simultan terhadap Variabel Loyalitas Karyawan.}

Hasil analisi data menunjukan bahwa koefisien hasil uji $\mathrm{F}$ sebesar 51.235 dengan tingkat signifikansi $0,000<0,05$, artinya variabel bebas $\mathrm{X} 1,2,3$ (pengembangan karir, kompensasi, karakteristik pekerjaan) secara simultan memiliki pengaruh positif dan signifikan terhadap loyalitas karyawan (Y), sehingga penelitian ini menerima hipotesis 4 yang menyatakan bahwa variable bebas (pengembangan karir, kompensasi, karakteristik pekerjaan) secara simultan mempunyai pengaruh yang positif dan signifikan terhadap variabel terikat (loyalitas karyawan). Penelitian ini juga memberikan bukti empiris bahwa perbaikan ketiga variabel tersebut akan mempengaruhi peningkatan loyalitas karyawan.

Selanjutnya, hipotesis 4 ini juga dikuatkan dengan hasil nilai adjusted $\mathrm{R}^{2}$ sebesar 0.604 , yang artinya bahwa bahwa kemampuan variabel bebas dalam menjelaskan besarnya pengaruh terhadap variabel terikat adalah sebesar 60,4\% yang sisanya dijelaskan oleh variabel lain diluar penelitian ini. Atau dengan kata lain variabel pengembangan karir, kompensasi dan karakteristik pekerjaan memiliki pengaruh sebesar 60,4\% terhadap loyalitas karyawan dan sisanya sebesar $39,6 \%$ dijelaskan oleh variabel lain diluar penelitian ini. 


\section{Simpulan}

Berdasarkan analisis data dan pembahasan tersebut diatas, maka dirumuskan simpulan sebagai berikut:

1. Variabel pengembangan karir $\left(\mathrm{X}_{1}\right)$ berpengaruh positif dan signifikan terhadap variabel loyalitas karyawan (Y) SPG dan SPB yang bekerja pada pertokoan di sepanjang jalan Malioboro, Yogyakarta. Hal ini didukung dengan hasil koefisien regresi sebesar 0,421 , thitung sebesar 5.976 dan nilai Sig. sebesar 0,000 < 0,05 . Oleh karena itu, hipotesis satu (H1) dapat diterima.

2. Variabel kompensasi $\left(\mathrm{X}_{2}\right)$ berpengaruh positif dan signifikan terhadap variabel loyalitas karyawan (Y) SPG dan SPB yang bekerja pada pertokoan di sepanjang jalan Malioboro, Yogyakarta. Hal ini didukung dengan hasil koefisien regresi sebesar 0,149 , thitung sebesar 2.030 dan nilai Sig. sebesar 0,045 < 0,05. Oleh karena itu, hipotesis dua (H2) dapat diterima.

3. Variabel karakteristik pekerjaan $\left(\mathrm{X}_{3}\right)$ berpengaruh positif dan signifikan terhadap variabel loyalitas karyawan (Y) SPG dan SPB yang bekerja pada pertokoan di sepanjang jalan Malioboro, Yogyakarta. Hal ini didukung dengan hasil koefisien regresi sebesar 0,411 , thitung sebesar 3.619 dan nilai Sig. sebesar 0,000 < 0,05 . Oleh karena itu, hipotesis tiga (H3) dapat diterima.

4. Secara simultan variable pengembangan karir $\left(\mathrm{X}_{1}\right)$, kompensasi $\left(\mathrm{X}_{2}\right)$ dan karakteristik pekerjaan $\left(\mathrm{X}_{3}\right)$ berpengaruh positif dan signifikan terhadap loyalitas karyawan (Y) SPG dan SPB yang bekerja pada pertokoan di sepanjang jalan Malioboro, Yogyakarta. Hal ini didukung de-

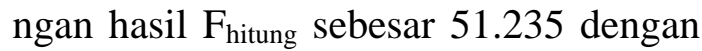
nilai Sig. sebesar $0,000<0,05$ dan nilai adjusted $\mathrm{R}^{2}$ sebesar 0.604 . Oleh karena itu, hipotesis empat (H4) dapat diterima.

\section{Implikasi}

Berdasarkan analisis data dan pengujian secara parsial (uji t) maupun simultan (uji F) dari variabel penelitian menunjukkan pengaruh yang positif dan signifikan, antara variabel bebas terhadap variabel terikat. Implikasi dari hasil penelitian ini adalah perbaikan dan peningkatan terhadap faktor-faktor yang mempengaruhui loyalitas karyawan harus benar-benar diperhatikan agar berdampak positif terhadap loyalitas karyawan. Dalam penelitian ini faktor faktor yang dipertimbangkan yaitu pengembangan karir, kompensasi dan karakteristik pekerjaan.

\section{Saran}

Dengan mempertimbangan realita ketatnya kompetisi dalam bisnis retail serta memperhatikan bukti empiris dari hasil penelitian ini, maka pengusaha dan manajemennya sebaiknya memberikan perhatian pada pengembangan karir, memperbaiki sistem kompensasi serta memperbaiki karakteristik pekerjaan sehingga loyalitas karyawan dapat terjaga.

Perbaikan loyalitas karyawan mengarah kepada tingkat kesetiaan karyawan dalam melaksanakan tugas yang telah dibebankan kepadanya. Kerena dengan loyalitas yang tinggi, karyawan akan bekerja dengan segenap kemampuan dan skill yang dimilikinya untuk bisa menghasilkan kinerja dan produktivitas yang memuaskan.

\section{Daftar Pustaka}

Amirin, Tatang M., (2011). "Populasi dan sampel penelitian 3: pengambilan sampel dari populasi takterhingga dan takjelas”, (Online). (Tatangmanguny.wordpress.com), di unduh 28 Juni 2016.

Darmawan, 2013. Metode Penelitian Kuantitatif. Bandung: Remaja Rosdakarya.

Dessler, Gary, 2016. Manajemen Sumber Daya Manusia, edisi 14. Jakarta: Salemba Empat.

Dwi Consultan, 2011. Analisis Regresi Linier Berganda (Online) (http://duwiconsultant.blogspot.co.id/2011/11/anali- 
sis-regresi-linier-berganda.html), diunduh 8 Juni 2016.

Gouzali, Saydam, 2005. Manajemen Sumber Daya Manusia: Suatu Pendekatan Mikro. Jakarta: Djambatan.

Griffin, Moorhead, 2013. Perilaku Organisasi Manajemen Sumber Daya Manusia dan Organisasi. Jakarta: Salemba Empat.

Kompasiana, 2014. Kriteria Model Statistik yang Baik. (Online).

http://www.kompasiana.com/jokoade/kriteria-model-statistik-yang-baik_54f6ad0da33311c55c8b45fa, (diunduh 20 Mei 2017).

Lestari, Puji, 2015. "Hubungan antara Pengembangan Karir dan Pemberian Insentif terhadap Loyalitas Kerja Karyawan pada PT. Komatsu Remanufacturing Asia Balikpapan”. Ejurnal Psikologi, 4 (2): 131-143.

Luthan, Fred, 2013. Perilaku Organisasi Edisi 10. Yogyakarta: ANDI.

Mangkunegara, A. A., Anwar Prabu, 2001. Manajemen Sumber Daya Manusia Perusahaan. Bandung: Remaja Rosdakarya.

Malayu S. P., Hasibuan, 2013. Manajemen Sumber Daya Manusia. Cetakan ketujuh belas. Jakarta: Bumi Aksara.

Mondy, R., Wayne, 2008. Manajemen Sumber Daya Manusia. Edisi kesepuluh, jilid 2. Jakarta: Erlangga.

Riani, Asri L., (2013). Manajemen Sumber Daya Manusia Masa Kini. Yogyakarta: Graha Ilmu.
Robins. Stephen P., (2016). Perilaku Organisasi. Jilid 2, edisi Bahasa Indonesia. Jakarta: PT. Prenhallindo.

Runtu, Julius, 2013. “Whistleblowing sebagai Ungkapan Loyalitas Karyawan: Peran Employability dan Keberanian Moral Karyawan”, (Online). (http://juliusruntu. blogspot.co.id/2014/02/indikator-loyalitas-karyawan-bahan.html). Diunduh 30 November 2016.

Safitri, Rahmadana, 2015. ”Pengaruh Kompensasi terhadap Loyalitas Karyawan PT. Putera Lautan Kumala Lines Samarinda”. Ejurnal Administrasi Bisnis, 3 (3): 650-660.

Sekaran, Uma, 2006. Research Methods for Business, Metodelogi Penelitian Untuk Bisnis. Jakarta: Salemba Empat.

Silvia, dkk., (2014). "Pengaruh Kompensasi dan Karakteristik Pekerjaan terhadap Loyalitas Karyawan”. Jurnal Progresif Manajemen Bisnis, 1(1): 1-10.

Sugiyono, 2010. Metode Penelitian Bisnis. Bandung : Alfabeta.

.2011. Metode Penelitian Kuantitatif Kualitatif dan R \& D. Bandung: Alfabeta.

SPSS Indonesia, Online. (http://www.spssindonesia.com/2014/02/cara-mudah-melakukan-uji-t-dengan-spss.html\#).

Veithzal, Rivai dan Ella, Jauvani. 2011. Manajemen Sumber Daya Manusia untuk Perusahaan. Edisi kedua. Jakarta: PT.Rajagrafindo Persada.

Wahyono, Sentot Imam. 2015. Manajemen Sumber Daya Manusia. Jakarta: Salemba Empat. 